\title{
Development and Validation of a Stability-Indicating Liquid Chromatographic Method for the Determination of Cefditoren Pivoxil in Presence of Degradation Products
}

\author{
M. MATHRUSRI ANNAPURNA* and B. VENKATESH
}

Department of Pharmaceutical Analysis \& Quality Assurance, GITAM Institute of Pharmacy, GITAM University, Visakhapatnam, India mathrusri2000@yahoo.com

Received 31 January 2014 / Accepted 19 February 2014

\begin{abstract}
A novel stability indicating liquid chromatographic method was developed for the determination of Cefditoren pivoxil in presence of degradation products using Zorbax SB C18 $(150 \mathrm{~mm} \times 4.6 \mathrm{~mm}$ i.d., $3.5 \mu \mathrm{m}$ particle size) column with a flow rate $1.0 \mathrm{~mL} / \mathrm{min}$ (UV detection $210 \mathrm{~nm})$. Linearity was observed over a concentration range $0.1-200 \mu \mathrm{g} / \mathrm{mL}$ with regression equation $\mathrm{y}=34809 \mathrm{x}+30603\left(\mathrm{R}^{2}=0.9994\right)$. Forced degradation studies were performed and Cefditoren pivoxil is reported to be highly sensitive towards alkaline conditions in comparison to oxidation. The method was validated as per ICH guidelines.
\end{abstract}

Keywords: Cefditoren pivoxil, Stability-indicating, Liquid chromatography, Validation, ICH

\section{Introduction}

Cefditoren pivoxil is a third-generation semi-synthetic cephalosporin antibiotic (Figure 1). It is effective in treating both gram-positive and gram-negative organisms and respiratory tract infections. It is chemically $(7 R)$ - 7-((Z)- 2-(2-aminothiazol- 4-yl)- 2-(methoxyimino) acetamido)- 3-((Z)- 2-(4-methylthiazol- 5-yl) vinyl)- 8-oxo- 5-thia-1-azabicyclo[4.2.0] oct2-ene- 2-carboxylic acid $\left(\mathrm{C}_{25} \mathrm{H}_{28} \mathrm{~N}_{6} \mathrm{O}_{7} \mathrm{~S}_{3}\right)$ with molecular weight $620.73 \mathrm{~g} / \mathrm{mol}$. It is a prodrug which is hydrolyzed by esterases during absorption, and the drug is distributed in the circulating blood as active Cefditoren ${ }^{1}$.

A thorough literature survey reports that very few analytical methods were reported for the determination of Cefditoren in biological fluids ${ }^{2-4}$ and in pharmaceutical dosage forms using HPLC $^{5-8}$, UPLC ${ }^{9}$ and spectrophotometry ${ }^{10}$. The authors have proposed a stability indicating liquid chromatographic method for Cefditoren pivoxil in presence of its degradation products.<smiles>CO/N=C(\C(=O)NC1C(=O)N2C(=C(/C=C/c3scnc3C)C(=O)OCOC(=O)C(C)(C)C)CS[13CH]12)c1csc(N)n1</smiles>

Figure 1. Chemical structure of Cefditoren pivoxil 


\section{Experimental}

Cefditoren pivoxil standard (purity 99.50\%) was obtained from Cipla Limited (India) and was used as it is without further purification. All other chemicals were of analytical grade (Merck). Cefditoren pivoxil is available as tablets (Label claim $200 \mathrm{mg}$ ) with brand names CEFTORIN® (Cipla Lmited, India) and ZOSTUM-O® (Zuventus, India).

\section{Instrumentation and chromatographic conditions}

Chromatographic separation was achieved by using Zorbax SB-C18 column $(150 \mathrm{~mm} \times 4.6$ $\mathrm{mm}$ i.d., $3.5 \mu \mathrm{m}$ particle size) for HPLC system of Shimadzu Model CBM-20A/20 Alite, equipped with SPD M20A prominence photodiode array detector, maintained at $25^{\circ} \mathrm{C}$.

Isocratic elution was performed using tetra butyl ammonium hydrogen sulphate: acetonitrile $(50: 50, \mathrm{v} / \mathrm{v})$ as mobile phase. The overall run time was $10 \mathrm{~min}$. with flow rate $1.0 \mathrm{~mL} / \mathrm{min}$ with UV detection at $210 \mathrm{~nm} .20 \mu \mathrm{L}$ of sample was injected into the HPLC system.

\section{Preparation of tetra butyl ammonium hydrogen sulphate buffer solution}

$3.3954 \mathrm{~g}$ of Tetra butyl ammonium hydrogen sulphate $(10 \mathrm{mM})$ was accurately weighed and dissolved in HPLC grade water in a $1000 \mathrm{~mL}$ volumetric flask ( $\mathrm{pH} 3.37)$.

\section{Preparation of stock solution}

Stock solution was prepared by accurately transferring about $10 \mathrm{mg}$ of Cefditoren pivoxil in to a $10 \mathrm{~mL}$ volumetric flask with mobile phase. Further dilutions were done on daily basis from the stock solution with mobile phase (tetra butyl ammonium hydrogen sulphate solution: acetonitrile, 50:50, v/v). Prior to injection all solutions were filtered through $0.45 \mu \mathrm{m}$ membrane filter.

\section{Method validation}

The method was validated for linearity, limit of quantitation (LOQ), limit of detection (LOD), intra/inter-day precision, accuracy, robustness and specificity ${ }^{11}$.

\section{Linearity}

Linearity test solutions for the assay method were prepared from a stock solution at different concentration levels of the assay analyte concentration $(0.1-200 \mu \mathrm{g} / \mathrm{mL}) .20 \mu \mathrm{L}$ of each solution was injected in to the HPLC system and the peak area of the chromatogram obtained was noted. A graph was drawn by taking the concentration of the drug on the $\mathrm{x}$-axis and the corresponding peak area on the $\mathrm{y}$-axis.

\section{Limit of quantification (LOQ) and limit of detection (LOD)}

The limit of quantification (LOQ) and limit of detection (LOD) were based on the standard deviation of the response and the slope of the constructed calibration curve as described in International Conference on Harmonization guidelines Q2 (R1).

\section{Precision}

The intra-day precision of the assay method was evaluated by carrying out 9 independent assays of a test sample of Cefditoren pivoxil at three concentration levels $(20,50$ and $100 \mu \mathrm{g} / \mathrm{mL}$ ) against a qualified reference standard. The \%RSD of three obtained assay values at three different concentration levels was calculated. 
The inter-day precision study was performed on three different days i.e. day 1, day 2 and day 3 at three different concentration levels $(20,50$ and $100 \mu \mathrm{g} / \mathrm{mL})$ and each value is the average of three determinations. The \%RSD of three obtained assay values on three different days was calculated.

\section{Accuracy}

The accuracy of the assay method was evaluated in triplicate at three concentration levels $(80,100$ and $120 \%)$ and the percentage recoveries were calculated. Standard addition and recovery experiments were conducted to determine the accuracy of the method for the quantification of Cefditoren pivoxil in the drug product. The study was carried out in triplicate at a total concentration 18,20 and $22 \mu \mathrm{g} / \mathrm{mL}$. The percentage recovery in each case was calculated.

\section{Robustness}

The robustness of the assay method was established by introducing small changes in the HPLC conditions which included wavelength $(208$ and $212 \mathrm{~nm})$, percentage of acetonitrile in the mobile phase (52 and $48 \%$ ), flow rate $(0.9$ and $1.1 \mathrm{~mL} / \mathrm{min})$ and $\mathrm{pH}(3.3$ and 3.5$)$. Robustness of the method was studied with $100 \mu \mathrm{g} / \mathrm{mL}$ of Cefditoren pivoxil.

\section{Analysis of commercial formulations (Tablets)}

Twenty tablets were procured from the local pharmacy store, weighed and crushed in to fine powder. Powder equivalent to about $10 \mathrm{mg}$ Cefditoren pivoxil was accurately transferred into a $10 \mathrm{~mL}$ volumetric flask and made up to volume with acetonitrile. The contents were sonicated for $30 \mathrm{~min}$ to enable complete dissolution of Cefditoren pivoxil and then the solution was filtered. The filtrate was further diluted with mobile phase to yield $100 \mu \mathrm{g} / \mathrm{mL}$.

\section{Forced degradation studies/Specificity}

Forced degradation studies were performed to evaluate the stability indicating properties and specificity of the method ${ }^{12}$. All solutions for use in stress studies were prepared at an initial concentration of $1 \mathrm{mg} / \mathrm{mL}$ of Cefditoren pivoxil and refluxed for $30 \mathrm{~min}$ at $80{ }^{\circ} \mathrm{C}$ in thermostat and then diluted with mobile phase to give a final concentration of $100 \mu \mathrm{g} / \mathrm{mL}$ All the solutions were analysed after $24 \mathrm{~h}$.

The acidic and alkaline degradations were performed using hydrochloric acid $(0.1 \mathrm{M})$ and in sodium hydroxide $(0.01 \mathrm{M})$ at $80{ }^{\circ} \mathrm{C}$ in a thermostat and the stressed samples were instantly cooled with a mixture of ice and water, neutralized and diluted with mobile phase as per the requirement. Oxidation was performed using $\mathrm{H}_{2} \mathrm{O}_{2}$ solution where as photolysis was performed on exposure of the drug solution to UV light $(365 \mathrm{~nm})$ for 6 hours in UV light chamber.

\section{Results and Discussion}

The authors have developed a validated stability indicating RP-HPLC method for Cefditoren pivoxil in presence of degradation products. A comparative study was done for the performance characteristics of the present stability indicating liquid chromatographic methods with the reported methods in the literature (Table 1).

\section{HPLC method development and optimization}

Initially the drug samples were analyzed using a mobile phase consisting of tetra butyl ammonium hydrogen sulphate buffer solution: acetonitrile $(50: 50, \mathrm{v} / \mathrm{v})$ with a flow rate of $0.8 \mathrm{~mL} / \mathrm{min}$ where the drug was eluted at $6.23 \mathrm{~min}$ with little tailing. Therefore the flow 
rate was modified to $1.0 \mathrm{~mL} / \mathrm{min}$ for which the retention time of the drug was eluted at $2.876 \mathrm{~min}$ (UV detection at $210 \mathrm{~nm}$ ) as a sharp peak without tailing and therefore the same chromatographic conditions were chosen for the entire study.

Table 1. Comparison of the performance characteristics of the present method with the published HPLC methods

\begin{tabular}{|c|c|c|c|c|}
\hline Method /Reagent & $\begin{array}{c}\lambda \\
\mathrm{nm}\end{array}$ & $\begin{array}{l}\text { Linearity } \\
\mu \mathrm{g} / \mathrm{mL}\end{array}$ & Remarks & Ref \\
\hline $\begin{array}{l}\text { Ammonium acetate: methanol: } \\
\text { acetonitrile }(50: 50, \mathrm{v} / \mathrm{v})\end{array}$ & 295 & $\begin{array}{c}(100- \\
4000) \times 10^{-3}\end{array}$ & Rat plasma & [3] \\
\hline $\begin{array}{l}\text { Methanol: Potassium dihydrogen } \\
\text { phosphate }(75: 25, \mathrm{v} / \mathrm{v})\end{array}$ & 231 & $40-120$ & $\begin{array}{l}\text { Narrow linearity } \\
\text { range }\end{array}$ & {$[5]$} \\
\hline $\begin{array}{c}\text { Water: Methanol } \\
\text { (adjusted to } \mathrm{pH}=6)(20: 80, \mathrm{v} / \mathrm{v})\end{array}$ & 256 & $3-30$ & $\begin{array}{l}\text { Very narrow } \\
\text { linearity range }\end{array}$ & {$[6]$} \\
\hline $\begin{array}{l}\text { Phosphate buffer }(\mathrm{pH} 8.0) \text { : } \\
\text { acetonitrile }(40: 60, \mathrm{v} / \mathrm{v})\end{array}$ & 220 & $0.1-200$ & Wide linearity range & [7] \\
\hline $\begin{array}{l}\text { Water-acetonitrile } \\
\quad(50: 50, \mathrm{v} / \mathrm{v})\end{array}$ & 218 & $0.1-250$ & $\begin{array}{l}\text { Isocratic mode } \\
\text { Stability indicating }\end{array}$ & [8] \\
\hline $\begin{array}{c}\text { Acetonitrile: Ammonium acetate } \\
\text { (pH 6.7) }\end{array}$ & - & $80-120$ & Gradient mode & [9] \\
\hline $\begin{array}{c}\text { TBHS: ACN } \\
\text { (isocratic mode) } \\
(50: 50, \mathrm{v} / \mathrm{v}) \\
\end{array}$ & 210 & $0.1-200$ & $\begin{array}{l}\text { Stability indicating } \\
\text { method with wide } \\
\text { linearity range }\end{array}$ & $\begin{array}{c}\text { Present } \\
\text { work }\end{array}$ \\
\hline
\end{tabular}

\section{Linearity}

The typical chromatogram obtained for Cefditoren pivoxil was shown in Figure 2A. Cefditoren pivoxil obeys Beer-Lambert's law over tconcentration range 0.1-200 $\mu \mathrm{g} / \mathrm{mL}$ (Table 2) with regression equation $y=34809 x+30603\left(r^{2}=0.9994\right)$ (Figure 3).

The LOQ and LOD were determined based on the 10 and 3.3 times the standard deviation of the response, respectively, divided by the slope of the calibration curve. The LOQ is found to be $0.0792 \mu \mathrm{g} / \mathrm{mL}$ and the LOD is found to be $0.0241 \mu \mathrm{g} / \mathrm{mL}$.

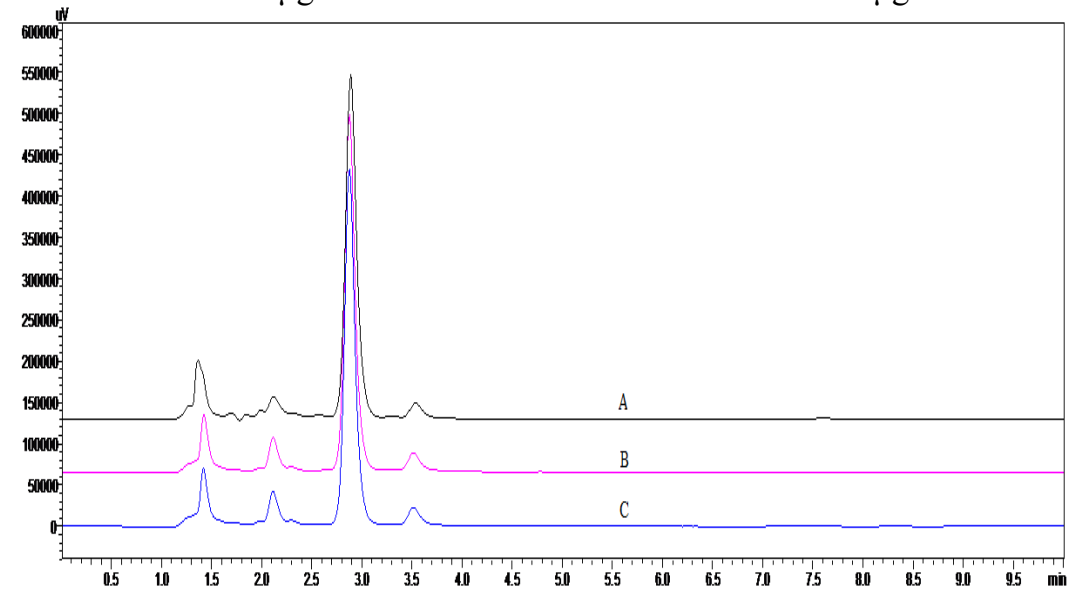

Figure 2. Typical Chromatograms of Cefditoren pivoxil (100 $\mu \mathrm{g} / \mathrm{mL})(\mathrm{A})$, CEFTORIN (B) ZOSTUM-O (C) (Label claim: $200 \mathrm{mg}$ ) 
Table 2. Linearity of Cefditoren pivoxil

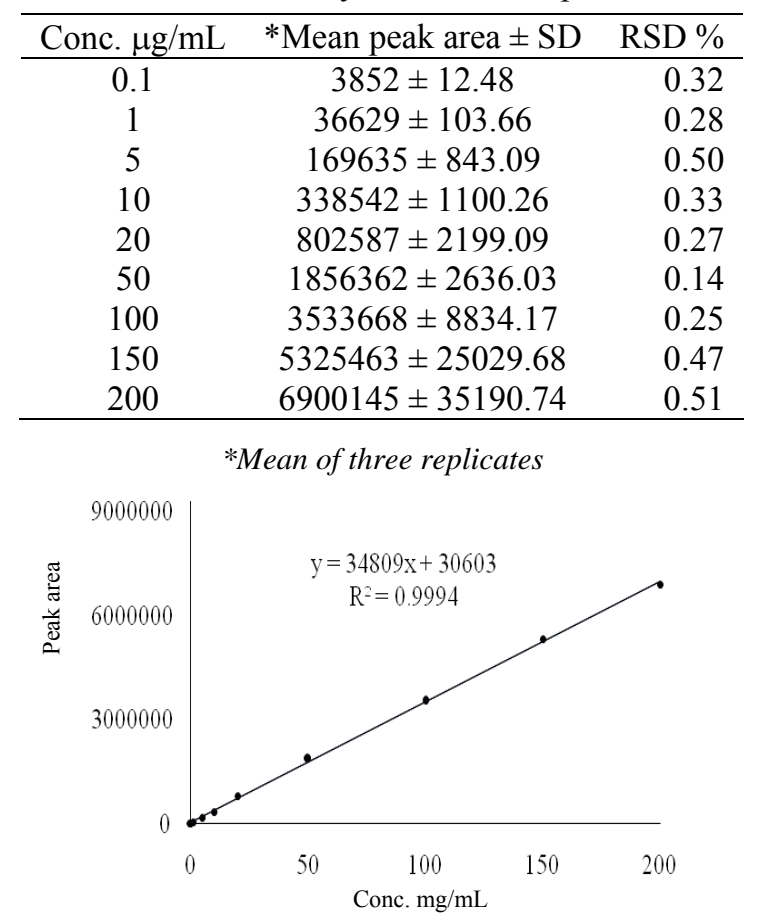

Figure 3. Calibration curve of Cefditoren pivoxil

\section{Precision and accuracy}

The \% RSD was found to be 0.76-0.99 (intra-day) and 0.49-0.96 (inter-day) in precision studies where as in accuracy studies the percentage recovery was found to be $98.87-98.97 \%$ with percentage RSD $0.44-0.46$ indicating that the method is precise and accurate (Table 3 ).

\section{Robustness}

The percentage RSD was found to be $98.87-98.98$ which is less than $2.0 \%$ indicating that the proposed method is robust (Table 4).

Table 3. Precision and accuracy studies of Cefditoren pivoxil

\begin{tabular}{ccccc}
\hline \multirow{2}{*}{$\begin{array}{c}\text { Conc. } \\
\mu \mathrm{g} / \mathrm{mL}\end{array}$} & ${ }^{*}$ Mean peak area \pm SD \%RSD & ${ }^{*}$ Mean peak area \pm SD \% RSD \\
\cline { 2 - 5 } 20 & $801561.00 \pm 7911.37(0.99)$ & $797571.33 \pm 4587.46(0.58)$ \\
50 & $1807286.33 \pm 14897.66(0.82)$ & $1836719.67 \pm 17559.51(0.96)$ \\
100 & $3514885.33 \pm 26718.79(0.76)$ & $3513687.67 \pm 17372.18(0.49)$ \\
\hline \multicolumn{5}{c}{ Accuracy } \\
\hline Spiked conc. & Total conc. & Mean peak area \pm SD & Drug found, & $\%$ \\
$\mu \mathrm{g} / \mathrm{mL}$ & $\mu \mathrm{g} / \mathrm{mL}$ & \% RSD & $\mu \mathrm{g} / \mathrm{mL}$ & Recovery \\
\hline $8(80 \%)$ & 18 & $650071.67 \pm 2824.20(0.46)$ & 17.80 & 98.87 \\
$10(100 \%)$ & 20 & $719660.00 \pm 3021.02(0.44)$ & 19.80 & 98.98 \\
$12(120 \%)$ & 22 & $788532.67 \pm 3350.70(0.44)$ & 21.77 & 98.97 \\
\hline
\end{tabular}

*Mean of three replicates 
Table 4. Robustness study of Cefditoren pivoxil

\begin{tabular}{ccccc}
\hline Parameter & Condition & $\begin{array}{c}{ }^{*} \text { Mean } \\
\text { peak area }\end{array}$ & $\begin{array}{c}{ }^{*} \text { Mean peak area } \pm \text { SD } \\
\text { \% RSD }\end{array}$ & $\begin{array}{c}{ }^{*} \text { Assay } \\
\%\end{array}$ \\
\hline Flow rate & 0.9 & 3493573 & $3532076.00 \pm 37732.20$ & \\
$( \pm 0.1 \mathrm{~mL} / \mathrm{min})$ & 1.0 & 3533668 & $(1.07)$ & \\
Detection & 1.1 & 3568987 & & \\
wavelength & 208 & 3535521 & $3522240.33 \pm 21418.09$ & \\
$( \pm 2$ nm $)$ & 210 & 3533668 & $(0.16)$ & \\
Mobile phase composition & 212 & 3497532 & & \\
$($ TBAHS: acetonitrile $)$ & $50: 50$ & 3533668 & $3528234.33 \pm 40548.48$ & \\
$( \pm 2 \%, \mathrm{v} / \mathrm{v})$ & $52: 48$ & 3565792 & $(1.15)$ & \\
pH & 3.3 & 3493546 & $3530997.00 \pm 36189.50$ & \\
$( \pm 0.1$ unit $)$ & 3.4 & 3533668 & $(1.02)$ & \\
\hline & 3.5 & 3565777 & &
\end{tabular}

\section{Analysis of commercial formulations (Tablets)}

The proposed method was applied to the determination of Cefditoren Pivoxil tablets and the assays was calculated as $98.70-99.22 \%$ (Table 5) and no interference was observed with the excipients Figure 2B and 2C.

Table 5. Analysis of Cefditoren pivoxil commercial formulation (Tablets)

\begin{tabular}{cccc}
\hline Formulation & Labeled claim, $\mathrm{mg}$ & ${ }^{*}$ Amount found, mg & ${ }^{*}$ Recovery, \% \\
\hline CEFTORIN & 200 & 197.40 & 98.70 \\
ZOSTUM-O & 200 & 198.44 & 99.22 \\
\hline
\end{tabular}

*Mean of three replicates

\section{Forced degradation studies/Specificity}

Cefditoren pivoxil was eluted at $2.883 \mathrm{~min}$ and when exposed to stress conditions the drug peak retains its symmetry as well as its retention time and did not interfere with the degradant peaks indicating the method is specific. The representative chromatograms obtained during the assay of stressed samples were shown in Figure 4a-4e. Cefditoren pivoxil was totally destroyed in alkaline environment. The carboxylic moiety present in the drug structure may be responsible for the total degradation in the alkaline condition. Figure $4 \mathrm{~b}$ shows the absence of Cefditoren pivoxil peak which has to be appeared at $2.8 \mathrm{~min}$. In alkaline degradation study extra peaks were observed at $1.372 \mathrm{~min}$ and at $1.597 \mathrm{~min}$ indicating that Cefditoren pivoxil is highly sensitive towards alkaline conditions. During the oxidation, Cefditoren pivoxil has shown $40.32 \%$ degradation indicating that the drug is less sensitive towards oxidation in comparison to alkaline environment. In oxidative stress extra peaks were observed at $1.399 \mathrm{~min}$ and at $1.973 \mathrm{~min}$ indicating that Cefditoren pivoxil is sensitive towards oxidation conditions. Cefditoren pivoxil has undergone 3.51, 5.20 and $4.97 \%$ degradation during acidic, thermal and photolytic degradations respectively which is less than $10 \%$ (Table 6). In all the studies Cefditoren pivoxil has reported theoretical plates more than 2000 and the tailing factor less than 1.5 indicating that the proposed method is selective. 
Table 6. Forced degradation studies of Cefditoren pivoxil

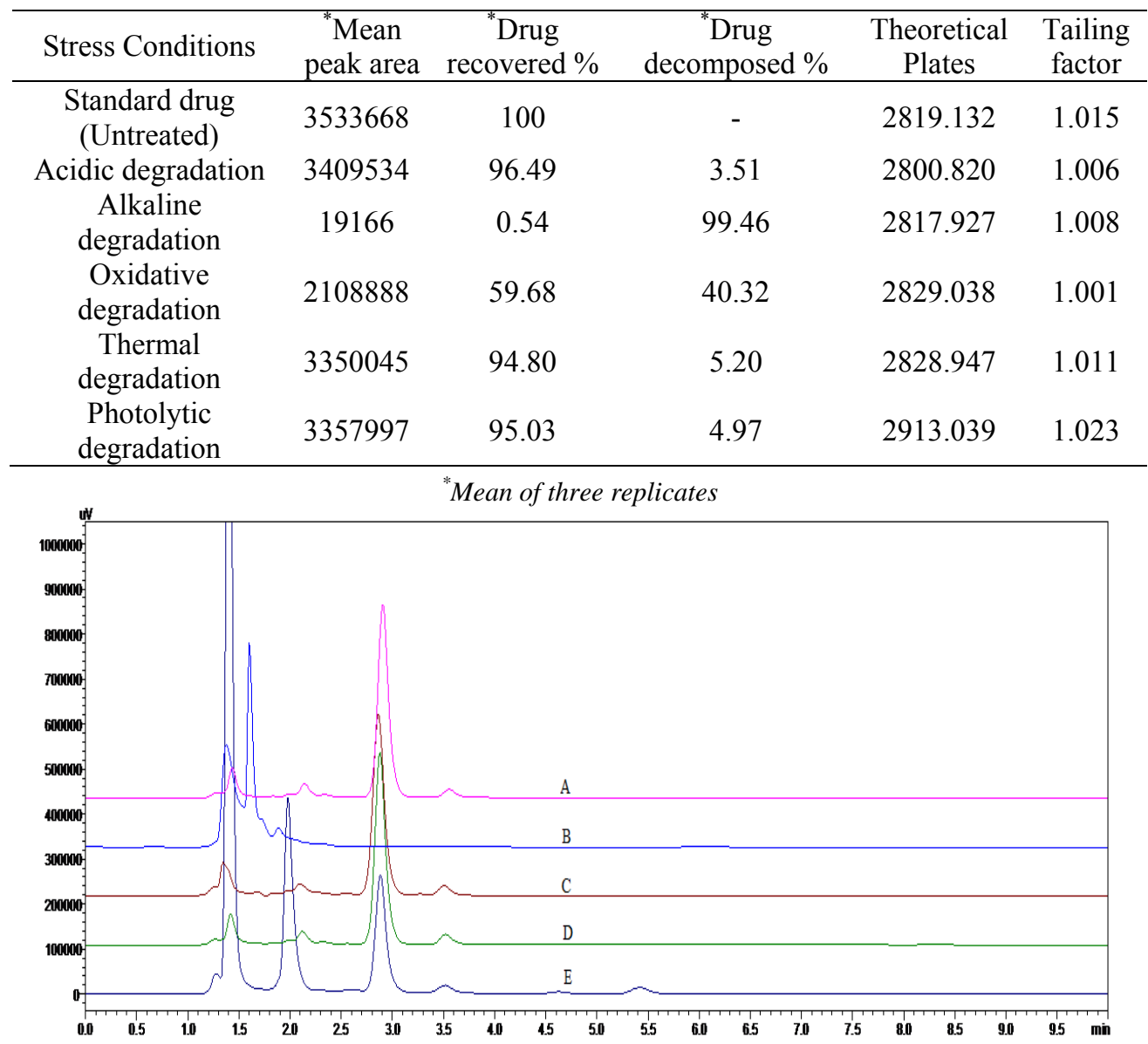

Figure 4. Typical Chromatograms of Cefditoren pivoxil on photolytic [A], alkaline [B], acidic $[\mathrm{C}]$, thermal $[\mathrm{D}]$ and oxidative $[\mathrm{E}]$ degradations

\section{Conclusion}

This stability-indicating and validated HPLC method is selective, precise, accurate and can be applied for the determination of Cefditoren pivoxil.

\section{Acknowledgment}

The authors are grateful to University Grants Commission, New Delhi for their financial support, M/s GITAM University for providing necessary research facilities.

\section{References}

1. Balbisi E A, Cefditoren, Pharmacotherapy, 2002, 22(10), 1278-1293.

2. Madhra Vishal D, Anurath S P, Ashwini M and Nimbalkar U, Int J Res Ayur Pharm., 2011, 2(5), 1582-1584.

3. $\quad$ Rieck W and Platt D, Clin Lab., 2000, 46(9-10), 477-482.

4. Liu Q, Yao J H and Su C Y, Asian J Pharmacodyn Pharmacokinet., 2006, 6(3), 214-218. 
5. Srinivasa Rao N and Saraswathi K J, Pharm Sci Res., 2011, 3(1), 1002-1004.

6. Dewani P, Kochar N I, Abooj H C, Bakal R L, Chandewar A V and Barik B B, J Pharm Res., 2010, 3(11), 2588-2591.

7. Mathrusri Annapurna M, Harika M and Madduri Sindhu S L, Drug Invention Today, 2012, 4(9), 470-474.

8. Mathrusri Annapurna, Goutam S V S, Anusha S and Srinivas L, J Pharm Anal., 2012, 2(6), 466-469.DOI:10.1016/j.jpha.2012.06.003

9. Garg R, Singh N, Srinivas K S, Binayak Deb and Ayaz Ahmed, J Appl Pharm Sci., 2011, 1(7), 149-153.

10. Raju S A, Karadi A B and Manjunath S, J Indian Council Chem., 2009, 26, 54-57.

11. ICH Validation of Analytical Procedures: Text and Methodology Q2 (R1), International Conference on Harmonization, 2005.

12. ICH Stability Testing of New Drug Substances and Products Q1A (R2), International Conference on Harmonization, 2003. 